\title{
Stakeholder co-creation during the innovation process: Identifying capabilities for knowledge creation among multiple stakeholders
}

Citation for published version (APA):

Kazadi, K., Lievens, A., \& Mahr, D. (2016). Stakeholder co-creation during the innovation process: Identifying capabilities for knowledge creation among multiple stakeholders. Journal of Business Research, 69(2), 525-540. https://doi.org/10.1016/j.jbusres.2015.05.009

Document status and date:

Published: 01/02/2016

DOI:

10.1016/j.jbusres.2015.05.009

Document Version:

Publisher's PDF, also known as Version of record

\section{Document license:}

Taverne

Please check the document version of this publication:

- A submitted manuscript is the version of the article upon submission and before peer-review. There can be important differences between the submitted version and the official published version of record. People interested in the research are advised to contact the author for the final version of the publication, or visit the DOI to the publisher's website.

- The final author version and the galley proof are versions of the publication after peer review.

- The final published version features the final layout of the paper including the volume, issue and page numbers.

Link to publication

\footnotetext{
General rights rights.

- You may freely distribute the URL identifying the publication in the public portal. please follow below link for the End User Agreement:

www.umlib.nl/taverne-license

Take down policy

If you believe that this document breaches copyright please contact us at:

repository@maastrichtuniversity.nl

providing details and we will investigate your claim.
}

Copyright and moral rights for the publications made accessible in the public portal are retained by the authors and/or other copyright owners and it is a condition of accessing publications that users recognise and abide by the legal requirements associated with these

- Users may download and print one copy of any publication from the public portal for the purpose of private study or research.

- You may not further distribute the material or use it for any profit-making activity or commercial gain

If the publication is distributed under the terms of Article $25 \mathrm{fa}$ of the Dutch Copyright Act, indicated by the "Taverne" license above, 


\title{
Stakeholder co-creation during the innovation process: Identifying capabilities for knowledge creation among multiple stakeholders
}

\author{
Kande Kazadi ${ }^{\mathrm{a}, *}$, Annouk Lievens ${ }^{\mathrm{a}}$, Dominik Mahr ${ }^{\mathrm{b}}$ \\ a Marketing Department, University of Antwerp, Faculty of Applied Economics, BE-2000 Antwerp, Belgium \\ b Department of Marketing E' SCM, Maastricht University, NL-6200 MD Maastricht, The Netherlands
}

\section{A R T I C L E I N F O}

\section{Article history:}

Received 23 September 2014

Received in revised form 8 February 2015

Accepted 18 May 2015

Available online 11 June 2015

\section{Keywords:}

Stakeholders

Co-creation

Innovation

Capabilities

Absorptive capacity

\begin{abstract}
A B S T R A C T
Extant research investigates a firm's ability to manage co-creation with one type of stakeholder during the innovation process, rather than co-creation with multiple stakeholders simultaneously. While such stakeholder co-creation creates benefits for the focal firm such as access to unique resources and knowledge bases, it also raises new challenges because of the diverse characteristics, interests and goals of the different stakeholders involved. Specific capabilities to anticipate and manage these challenges are therefore of particular interest for research and practice. The study here narrows this gap by conducting an in-depth case study, examining multiple stakeholder co-creation projects embedded within a pharmaceutical firm. The study develops a contingency framework on the role of four stakeholder co-creation capabilities in generating valuable knowledge. Overall, these findings complement extant literature by examining how specific capabilities employed before and during the innovation project may explain differential performance of stakeholder co-creation activities.
\end{abstract}

(c) 2015 Elsevier Inc. All rights reserved.

\section{Introduction}

The ability of firms to create knowledge during the innovation process has been identified as a key source of competitive advantage (Bierly, Damanpour, \& Santoro, 2009; Grant, 1996). In recent years, firms have realized that such knowledge creation cannot happen solely within the firm. To expand their knowledge base, firms increasingly cocreate knowledge with external stakeholders during the innovation process (Hoyer, Chandy, Dorotic, Krafft, \& Singh, 2010; Mahr, Lievens, \& Blazevic, 2014). For example, leading car brands such as BMW engage thousands of consumers across the world to co-create innovative features in new cars (Poetz \& Schreier, 2012). Various streams of marketing and management literature have detailed this process by which firms integrate one type of external stakeholder in their innovation process (Horn \& Brem, 2013). In particular, an emergent stream of research focuses on the use of latest technologies to harness contributions from empowered consumers. Through collaborative and competitive mechanisms, individuals create ideas for new product designs, develop additional functionalities, or solve R\&D problems (Horn \& Brem, 2013; Hoyer et al., 2010). Similarly, a growing stream of research investigates collaborations during the innovation process between two or more organizations (Gnyawali \& Park, 2011; Möller \& Törrönen, 2003; Song \& Thieme, 2009).

\footnotetext{
* Corresponding author. Tel.: + 32471359596.

E-mail address: kande.kazadi@uantwerpen.be (K. Kazadi).
}

Remarkably though, despite the proliferation of research related to co-creation, few studies consider firms that simultaneously include a diverse set of stakeholders in their innovation projects. Yet, in practice, firms increasingly engage in stakeholder co-creation projects, in which one firm includes a multitude of stakeholders during the innovation process. We define stakeholder co-creation as collaborative activities during which multiple interdependent external stakeholders contribute to a firm's innovation process (Gebauer, Füller, \& Pezzei, 2013; Hoyer et al., 2010; Mahr et al., 2014). For example, the logistics provider DHL invites academics, politicians, public authorities, and citizens to help it develop city logistics concepts that can reduce the challenge of decreasing urban traffic and embrace a greener economy (Cuccureddu, 2011). Such expanded collaboration creates opportunities for unique knowledge creation, as certain types of stakeholders have access to resources that are not readily available through market transactions, such as detailed insight into utility functions of consumers (Gulati, 1999; Harrison, Bosse, \& Phillips, 2010). Yet, concurrently, these socially complex interactions create new challenges for firms. Indeed, bringing a diverse group of stakeholders together leads to potential divergent goals and interests, communication difficulties, distrust among stakeholders, or conflict over value appropriation (Waligo, Clarke, \& Hawkins, 2014). Previous research, focusing on the management of co-creation during the innovation process, has not fully considered these challenges. As a result, previously identified capabilities are tailored towards co-creation with one type of stakeholder.

Organizational capabilities allow firms to manage their resources in such a way, that they create a competitive advantage. Indeed, from a 
resource-based view (RBV) perspective, these external stakeholders are resources which may create valuable knowledge for the firm (Driessen \& Hillebrand, 2013; Waligo et al., 2014). Therefore, an understanding of the capabilities required by a lead firm to manage stakeholder cocreation projects is important for research and practice (Garnier, 2008; Harrison et al., 2010). Such capabilities allow firms to reap the benefits from stakeholder co-creation better than other firms (Cepeda \& Vera, 2007; Menguc, Auh, \& Yannopoulos, 2014). Consequently, stakeholder co-creation capabilities may drive a firm's competitive advantage.

Thus, the purpose of this study is to improve our understanding of how knowledge is co-created with multiple stakeholders simultaneously, and which capabilities a lead firm requires to manage this knowledge co-creation process. In addressing these issues, we take a theoretical posture nested in the resource-based view of the firm and the concept of absorptive capacity. From a RBV perspective, external stakeholders are unique knowledge resources that can create value for the lead firm (Garcia-Castro \& Aguilera, 2015). A firm's absorptive capacity is its ability to recognize the value of new, external information, assimilate it, and apply it to commercial ends (Cohen \& Levinthal, 1990). Both perspectives underscore the need for capabilities to manage resources in such a way that they create valuable knowledge for the firm's current and future operations. Yet, both perspectives have their shortcomings to fully explain the capabilities required for successful stakeholder cocreation. By linking both perspectives to stakeholder co-creation, we offer several key contributions addressing these shortcomings.

First, an important criticism on the RBV is that a firm's resources are not a sufficient explanation of competitive advantage (Menguc et al., 2014). Consequently, we follow other scholars in the rationale that these resources need to be matched with organizational capabilities to deploy them in such a way that they create value for the firm (Day, 1994; Grant, 1996; Menguc et al., 2014). Consequently, a first contribution of this study is to identify the capabilities required to manage stakeholders as unique knowledge resources. We do this by linking the emerging literature on co-creation with the resource-based view and literature on organizational capabilities. In doing so, we answer research calls for more insight in the capabilities required to successfully manage co-creation activities (Lindgreen, Hingley, Grant, \& Morgan, 2012).

Second, a common critique of organizational capabilities literature is that identified capabilities remain vague, abstract, or static, without offering an in-depth understanding of these capabilities (Kraaijenbrink, Spender, \& Groen, 2010). Without clarification of the routines and individual skills that are the building blocks of each capability, we are limited to an abstract representation. The current study first identifies specific capabilities that strengthen co-creation activities before and during the innovation project. Then, it explicates a set of microfoundations of each of the identified capabilities, thereby recognizing the multilayered nature of capabilities. In this sense it opens a "black box" and breaks down theoretical entities in component elements (Salvato \& Rerup, 2011), which enables increased insight in performance heterogeneity, even when firms possess seemingly similar capabilities.

Third, a firm's absorptive capacity is its ability to recognize the value of new, external information, assimilate it, and apply it to commercial ends (Cohen \& Levinthal, 1990). This concept receives wide recognition (Volberda, Foss, \& Lyles, 2010). However, it also receives criticism in the sense that past studies apply absorptive capacity as a one-dimensional high-level construct (Bierly et al., 2009). Following Lane, Koka, and Pathak (2006), the current study contributes to the absorptive capacity literature by explicitly addressing the capabilities that relate to the context of knowledge co-creation with multiple stakeholders. In doing so, the study examines a specific subset of underlying capabilities of absorptive capacity, rather than seeing absorptive capacity as a single high-level construct.

To gain these insights, the study here employs an exploratory, embedded case study method. With this method, we can understand and identify new constructs that are part of the complex, multilevel phenomenon (Dubois \& Gadde, 2014; MacInnis, 2011; Salvato \& Rerup, 2011). We purposefully selected a global health care and pharmaceutical company as our research setting. This industry is experiencing a radical transition, is subject to constant pressures for innovation, and features a wide range of stakeholders in which each are becoming more active and empowered (Pullen, de Weerd-Nederhof, Groen, \& Fisscher, 2012). Within this context, we examine two embedded cases, which differ in their levels of stakeholder diversity as well as their original purpose, making them a rich setting to explore the complex phenomenon of stakeholder co-creation (Dubois \& Gadde, 2014).

The theoretical framing motivates structuring the article as follows. Section 2 is a literature review on co-creation during the innovation process and the link with organizational capabilities and absorptive capacity. Section 3 explains the study's applied case study method. Section 4 presents findings on how knowledge is co-created with multiple stakeholders and how four specific organizational capabilities strengthen this knowledge creation. These capabilities are stakeholder networking capability, stakeholder competence mapping, stakeholder relational capability and stakeholder knowledge management capability. The article concludes with formulating the major implications for the literature on stakeholder co-creation and the limits and potential for further extension of this work.

\section{Theoretical background}

\subsection{Stakeholder co-creation of value during the innovation process}

Today's competitive environments require firms to increasingly focus on the creation of valuable knowledge to remain competitive (Hsiao, Tsai, \& Lee, 2012). A single firm only has a limited set of resources in its possession to create such knowledge. Therefore, it may benefit from collaborating with other actors to create unique knowledge during the innovation process. Subsequently, firms have opened their innovation processes to involve external actors.

The types of actors involved define the type of knowledge created (Ritter \& Gemünden, 2003). While most of the actors that have been explored thus far are primary stakeholders, such as customers (Coviello \& Joseph, 2012), competitors (Amaldoss \& Rapoport, 2005) or suppliers (Song \& Thieme, 2009), research and practice have shown a shift towards collaborating with multiple stakeholder simultaneously during the innovation process. This paradigm shift is driven by two important trends. First, firms increasingly require complex knowledge during their innovation process. Such complex knowledge requires the input of multiple (external) parties (Day, 2011; Hsiao et al., 2012). Second, stakeholders are becoming increasingly empowered, interconnected and willing to share their knowledge and ideas with firms (Fuchs, Prandelli, Schreier, \& Dahl, 2013; Gebauer et al., 2013). Such active participation has not always been the focus of stakeholder theory.

Stakeholder theory refers to the management of a firm's relationships with a wide range of stakeholders (Freeman, 1994). Stakeholder theorists acknowledge that organizations need to inform themselves about stakeholder issues (Donaldson \& Preston, 1995; Driessen, Kok, \& Hillebrand, 2013). Yet, it was not until the recent years that research has focused on how to manage the various tensions that arise by integrating stakeholder issues in decision making processes (Driessen et al., 2013). In a subsequent step, rather than only acknowledging stakeholder needs, firms increasingly involve multiple stakeholders in their decision making process (Waligo et al., 2014). Pretty (1995) identifies two schools of thought regarding participation of stakeholders: (1) using stakeholder integration to drive adoption or (2) seeing stakeholder integration as a fundamental right of those stakeholders. However, in recent years, firms have realized that stakeholder integration may benefit the firm in a more active way where empowered stakeholders are potential sources of unique knowledge during the innovation process. 
Innovation network theory may also shed light on how firms may integrate multiple stakeholders during the innovation process. In many industries, the locus of innovation is not the individual firm but rather its network (Dyer \& Singh, 1998; Powell, Koput, \& Smith-Doerr, 1996; Ritter \& Gemünden, 2003). Innovation networks combine dispersed resources, knowledge, and capabilities (Perks \& Moxey, 2011: Ritter \& Gemünden, 2003), which often are not readily available through market transactions (Gulati, 1999). This combination is becoming increasingly important because of the increased complexity of new products and services (Pullen et al., 2012). Previous work has shown that in such networks, a lead firm plays a key role in orchestrating its network (Dhanasai \& Parkhe, 2006) but demands a specific set of capabilities. Recent marketing and management literature thus investigate a lead firm's ability to structure and manage its network to enhance its innovativeness and overall results (Capaldo, 2007; Dhanasai \& Parkhe, 2006; Perks \& Moxey, 2011).

In traditional innovation networks, multiple actors all represented similar types of stakeholders, but nowadays, sources of innovation are varied (Perks \& Jeffery, 2006). They include customers, suppliers, government, competitors, NGOs and many other special interest groups-all active nodes in innovation networks that provide complementary knowledge and experience for value co-creation (Driessen \& Hillebrand, 2013; Ramaswamy \& Gouillart, 2010). These different types of actors can enter into trust-based relationships with the lead firm, and maintaining these relationships in turn can drive increased market insights and revenues (Ramaswamy \& Gouillart, 2010). During the development of products and services different types of stakeholders represent active, empowered actors in the lead firm's innovation network. These diverse stakeholder types have different goals, needs and communication styles. Therefore, firms need to reinvestigate the specific capabilities that a firm needs to manage its innovation networks, when those networks no longer consist of other firms.

\subsection{The resource-based view of the firm and organizational capabilities}

The resource-based view regards firms as heterogeneous bundles of resources (Amit \& Schoemaker, 1993). Resources that are valuable, rare, inimitable, and non-substitutable enable firms to gain sustainable competitive advantages, though in contemporary, high-velocity markets, few resources remain that meet all four criteria (Eisenhardt \& Martin, 2000). Firms seemingly should perform homogeneously then, yet different firms still perform heterogeneously. According to the organizational capabilities approach, this heterogeneity in performance can be explained through the study of a firm's capabilities.

Organizational capabilities reflect the firm's ability to deploy its resources in such a way that they create competitive advantage (Amit \& Schoemaker, 1993; Day, 1994; Grant, 1996). The current study takes a similar theoretical stance to approach our research question. Indeed, a firm's stakeholders are unique knowledge resources. Yet, in order to create a competitive advantage, firms need the appropriate capabilities to manage the socially complex process of involving multiple stakeholders simultaneously during the process. Such stakeholder cocreation capabilities follow Teece, Pisano and Shuen's (1997) definition of dynamic capabilities. Dynamic capabilities are a firm's ability to integrate, build and reconfigure, internal and external competences or resources to address rapidly changing customer and technological environments (Cepeda \& Vera, 2007; Eisenhardt \& Martin, 2000; Teece, 2007).

A common critique of studies on organizational capabilities is that the lower levels of analysis receives scant attention (Abell, Felin, \& Foss, 2008; Felin, Foss, Heimeriks, \& Madsen, 2012). At these lower levels are the microfoundations of a capability, that is, its constituent components or building blocks. These individual skills and routines, and their interactions, underlie each specific capability (Abell et al., 2008; Felin et al., 2012). A routine is a repeated action, which may reflect the heuristics for how the organization gets things done (Lewin, Massini, \& Peeters, 2011).

As Felin et al. (2012) observe, most science begins by looking at aggregate-level phenomena, with the general assumption that microlevel phenomena have relatively uniform effects. As scientific research progresses, such assumptions usually prove unsustainable. For example, multiple studies show that variation on the individual level causes substantial variation in firm-level learning (Cohen \& Levinthal, 1990; Felin et al., 2012). Thus, a clear understanding of a phenomenon demands a microfoundational view (Volberda et al., 2010). This observation holds for the study of co-creation capabilities too. Several studies have denoted which capabilities lead to competitive advantages (see our literature review), but we lack an in-depth understanding of the inner mechanisms of these specific co-creation capabilities.

\subsection{Absorptive capacity as a higher-level capability}

Transferring knowledge from one partner to another is typically discussed in the literature on absorptive capacity. Absorptive capacity is a key for firms that look to build knowledge through collaboration with external partners (Zahra \& George, 2002). Given firms' increasing focus on such external collaboration, the absorptive capacity construct has developed as a key determinant of competitive advantage (Huang et al., 2015; Volberda et al., 2010). Indeed, Zahra and George (2002) frame absorptive capacity as a higher-level capability that allows firms to deploy their knowledge resources in such a way that they create a competitive advantage. Although the concept is widely used, few studies have examined the specific organizational capabilities that underlie this high-level absorptive capacity construct. As such, absorptive capacity has often remained a black box (Bierly et al., 2009; Huang et al., 2015; Lewin et al., 2011). Therefore, we set out to identify specific organizational capabilities, within this higher level construct of absorptive capacity, that contribute to the co-creation of knowledge with multiple stakeholders during the innovation process.

Fig. 1 exemplifies our theoretical framing visually. By specifically focusing on these capabilities, we recognize that the specific dimensions of absorptive capacity are related to the specific nature of the environment and context in which knowledge is co-created (Volberda et al., 2010). In doing so, we aim to overcome some of the limitations of the extant literature which has mainly focused on proxy measures of absorptive capacity (e.g. R\&D expenditure), rather than its core components (Lewin et al., 2011). An important implication is that this study does not aim at providing an overview of all capabilities underlying absorptive capacity. Instead, we focus on specific capabilities related to co-creation during the innovation process with multiple stakeholders (Van Den Bosch, Volberda, \& De Boer, 1999).

\subsection{Stakeholder co-creation capabilities in current literature}

Current literature on specific capabilities that a firm requires to manage co-creation during the innovation process, predominantly focuses on the inclusion of one specific type of external stakeholder during the innovation process, such as competitors, customers or suppliers. For example, alliance management capability has been identified as a key driver of knowledge transfer success (Leischnig, Geigenmueller, \& Lohmann, 2014; Schreiner, Kale, \& Corsten, 2009). However, it does not encompass the complexity that arises when collaborating with different types of stakeholders simultaneously. Therefore, where capabilities have been identified to manage co-creation, it is mostly directed at the specific challenges of including one type of stakeholder. Similarly, literature on the relational view takes the perspective that only relationships between firms are within the unit of analysis (Dyer \& Singh, 1998). Across the fields of marketing and management, some scholars have focused on the phenomenon of firms involving multiple stakeholders during their innovation process, yet several theoretical gaps still remain. 


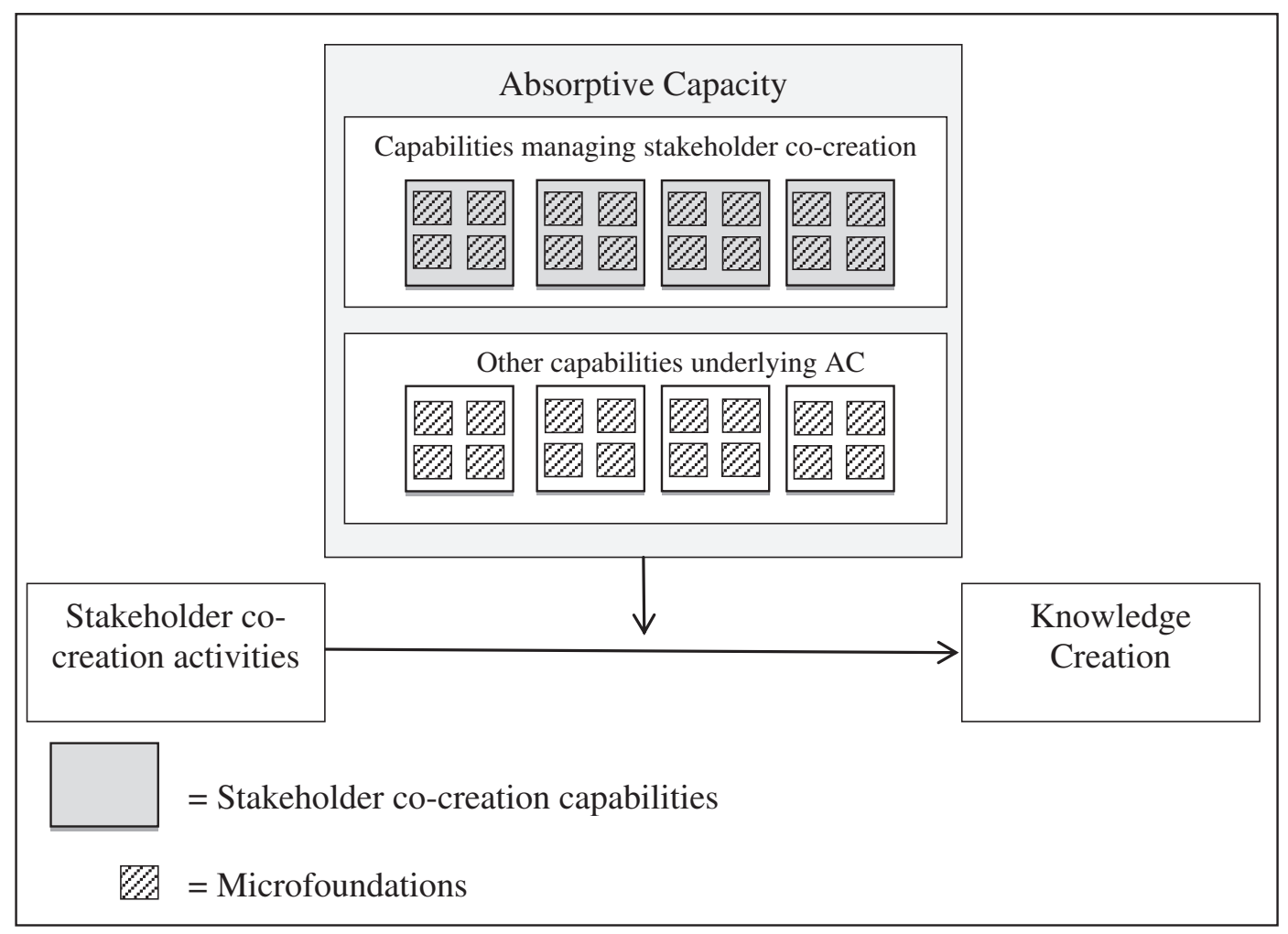

Fig. 1. Theoretical framing.

First, many studies investigate stakeholder co-creation from the network-level of analysis. For example, Arikan (2009) introduces the concept of a cluster's knowledge creation capability and develops a model that outlines the antecedents of this capability. However, the author explains that the study's findings are predominantly targeted at the cluster level of analysis (Arikan, 2009). The current study aims to identify capabilities which are deployed at the firm-level and allow a lead firm to create knowledge with a multitude of its stakeholders.

Second, studies mainly consider stakeholders that are part of the supply-chain. Indeed, Huikkola, Ylimäki, and Kohtamäki (2013) discuss relational practices enabling a joint-learning capability between customers and suppliers. The findings of this study are mainly targeted at situations where both stakeholders are firms. For example, the authors call for both stakeholders to make investments into relationship IT systems and dedicated personnel to benefit the relationship. Such findings would be difficult to apply when a firm conducts co-creation activities with stakeholders that are not organizations, such as consumers or special interest groups. Similarly, Malhotra, Gosain, and El Sawy (2005) examine supply-chain partnership configurations that exist based on variations in capability platforms. Such capability platforms reflect processes and information systems shared between the supply-chain partners. Typically, nonmarket stakeholders are not considered in such capability platforms, even though they might offer significant opportunities for knowledge co-creation during NPD (Driessen \& Hillebrand, 2013). Therefore, the authors call for further investigation that examines other configurations of partnerships for knowledge creation (Malhotra et al., 2005). Similarly, Harrison et al. (2010) discuss how firms create increased value by allocating additional resource to managing stakeholder needs and demands. However, the authors only consider primary stakeholder, within a firm's supply-chain (Harrison et al., 2010). Furthermore, the authors call for increased research into a firm's capabilities required to translate cooperation with multiple stakeholders into valuable knowledge (Harrison et al., 2010).

Third, studies that do consider stakeholders, other than supplychain partners, typically see these stakeholders as information sources, rather than active co-creators during the innovation process. Driessen and Hillebrand (2013) discuss the nature, antecedents and consequences of stakeholder integration capability. While the study considers the integration of a wide range of stakeholders during NPD, it is predominantly focused on stakeholders that voice issues with a firm's products or services rather than co-creation during the innovation process. Therefore, the authors also call for further investigation into actively involving a wide range of stakeholders during the innovation process (Driessen \& Hillebrand, 2013).

In sum, the literature review illustrates that research does fully explore the potential of firms to create knowledge with multiple stakeholders during the innovation process. The present study advances research by identifying the capabilities that firms require to manage the specific challenges presented by stakeholder co-creation.

\section{Method}

Because of the emergent nature of this topic, we opt for an exploratory case study. A case study is appropriate when a contemporary phenomenon is being investigated in its real-life context and the boundaries of the phenomenon are not clearly defined (Eisenhardt \& Graebner, 2007; Waligo et al., 2014; Yin, 2009). Embedded case studies are case studies containing more than one subunit of analysis. The identification of specific subunits within the overall case setting allows for a more detailed level of inquiry (Yin, 2009). It is specifically appropriate to describe the context, features and processes within a phenomenon. Furthermore, it is well suited to investigating microlevel activities, because it allows researchers to examine enacted processes in detail (Perks, Gruber, \& Edvardsson, 2012).

Our research process was abductive, which is a more useful research approach when a research project is geared towards discovery (Dubois \& Gadde, 2014; Suddaby, 2006). The goal is to match theory and reality in a nonlinear, path-dependent process that systematically combines empirical observations and insights from extant literature (Dubois \& Gadde, 2002; Storbacka, 2011). Therefore, the first author was in close 
continuous contact with the focal company for several months between 2011 and 2012, continuously going back and forth between evidence from the case study and theoretical foundations of the earlier mentioned literature streams. This allowed us to modify our tentative framework iteratively with empirical evidence and theoretical insights gained in the research process. The second and third author kept an outside perspective during the iterative data collection (Gioia, Corley, \& Hamilton, 2013).

\subsection{Research context}

The pharmaceutical industry confronts decreasing research and development (R\&D) productivity, rising commercialization costs, legal entanglements, pricing pressures and shorter exclusivity periods (Garnier, 2008; Hughes \& Wareham, 2010). As a result of this turbulence, a modern trend emphasizes collaborations with external partners (Hughes \& Wareham, 2010). Concurrently, a wide range of pharmaceutical industry stakeholders, such as patients, physicians, pharmacists, health-care providers, R\&D-focused enterprises, diagnostic companies, NGOs, universities, venture capitalists, and governments have become more active and empowered. The greater availability of information and technological advances has transformed previously passive actors into empowered, potential partners, which in turn has made markets even more complex. Such market pressures demand new strategies for dealing with and benefiting from empowered stakeholders (Agarwal \& Helfat, 2009). Noting these developments, we selected a leading global health care and pharmaceutical company, with over 100,000 employees worldwide, as our research setting.

\subsection{Case selection}

Following Eisenhardt and Graebner (2007); and Dubois and Gadde (2002), we selected embedded cases to extend emergent theory. Our initial literature review and research questions led us to choose two embedded cases within our pharmaceutical firm case setting, both of which involved a health care innovation project that included a multitude of stakeholders. When a research problem is directed towards the analysis of a complex set of interrelated variables, it is appropriate to limit the number of cases, aiming for depth rather than breadth. This research design allows us to analyze the stakeholder co-creation process in a common context around the subcases. These subcases are then subject to a firm's capabilities and can thus be analyzed in their shared context (Dubois \& Gadde, 2002). In line with this, the embedded cases were selected aiming at theoretical replication rather than literal replication (Yin, 2009). Because of the explorative nature of this study, we selected two projects that differed on two key dimensions, providing the best chance of identifying patterns of difference and similarity (see Fig. 2).

First, they exhibited different levels of heterogeneity in the actors participating in the co-creation project. Such heterogeneity has the potential to influence the type of knowledge that gets co-created (Möller \& Törrönen, 2003). Although it introduces multiple divergent perspectives, diversity also might create conflict in project teams if the various actors have conflicting goals or values. Conflict demands special capabilities of the lead firm (Driessen \& Hillebrand, 2013). Therefore, one project consisted of multiple stakeholders from a similar industry, but the other project brought actors together from very dissimilar industries. Second, the cases differed in the goals they established for the cocreation project. In particular, we recognized that stakeholder cocreation has the potential to create short-term, exploitative or longterm, exploratory knowledge (Atuahene-Gima, 2005; Lin, McDonough, Lin, \& Lin, 2012). These two knowledge categories can create paradoxes for firms, in that too much focus on either form could induce failure (Lin et al., 2012). Therefore, we considered short- versus long-term goals as a selection dimension. Both embedded cases as such offered empirical evidence to iteratively develop our final theoretical framework (Yin, 2009).
The focal firm contact was a general director who oversaw all development projects. To work with him to select projects, we explained our sampling method and the selection dimensions. Project Alpha focused on developing a new way to treat a medical condition that affected children through a collaboration with a game-development organization, parents' association, and medical experts. The firm already had products on the market to treat this condition, so the project aimed to contribute to its short-term, existing business. The nine-headed project team consisted of persons from different departments inside our focal organization, a parent association, and a medical doctor, such that they mostly emerged from the same overarching industry (i.e., health care). A game development company consulted on the project too, though on a more transactional basis. Other partners, such as a children's television production company, were involved only indirectly.

Project Beta instead focused on new ways to deliver medical supplies to remote areas in developing countries and sought a long-term plan for gaining better access to these markets. The focal company collaborated with an NGO, a fast-moving consumer goods company, and local governments; the project team consisted of two representatives of the NGO, members of diverse functional areas of the focal company, representatives of local governments, and members of the consumer goods company. In this sense, the diversity of actors was considerably higher in Project Beta than in Project Alpha.

\subsection{Data collection and analysis}

To increase the validity of the case study, we relied on triangulated data collection methods, which can overcome limitations and biases by counterbalancing them with the strengths of other data collection methods (Jick, 1979). We used four main data sources: publicly accessible company documents related to both projects; internal company documents, available through company headquarters; semi-structured interviews with internal and external project members; feedback sessions with managers.

In total, face-to-face visits were conducted in the focal firm 17 times and gathered 17 pages of publicly accessible material related to the projects. The focal company and two external stakeholders also provided the equivalent of 32 pages of electronic documentation. Then we accessed 42 pages of internal documentation from the focal company's offices. More than $16 \mathrm{~h}$ of interview recordings were transcribed for analysis. Finally, the lead author maintained a notebook of observations at the lead company site, which amounted to 19 pages. Combining interviews with secondary data (e.g., company documents) helped us balance the strengths of obtrusive and unobtrusive measures (Jaworski \& Kohli, 1993) and gain in-depth, qualitative insights while avoiding social desirability or ego protection biases.

To analyze the collected data, we followed an iterative, rather than a linear process of subsequent stages. Hence, we constantly went back and forth from one type of research activity to another. This systematic combining approach, consistent with Dubois and Gadde (2002), consisted of four iterative phases: articulating preconceptions; empirical observation; interpretation; and redirection. First, we entered the interview process with a well-defined focus, based on our initial literature review. We specified a-priori constructs, which helped shape the design of our case study research for theory building, in line with extant constructs (Dubois \& Gadde, 2002, 2014). Table 1 gives an overview of the a-priori constructs considered.

Second, we confronted our theoretical preconceptions with empirical observations. We entered each recorded interview and all collected documents into QSR Nvivo 9, a widely accepted tool for performing qualitative research (Gebhardt, Carpenter, \& Sherry, 2006). In Table 2, we summarize the interviews, which included key informants from the focal company and members of stakeholder organizations. Selection criteria were: (1) the informants' participation throughout all stages of the project's NPD process; (2) their involvement in the communication with other stakeholders, and (3) their willingness to participate and 


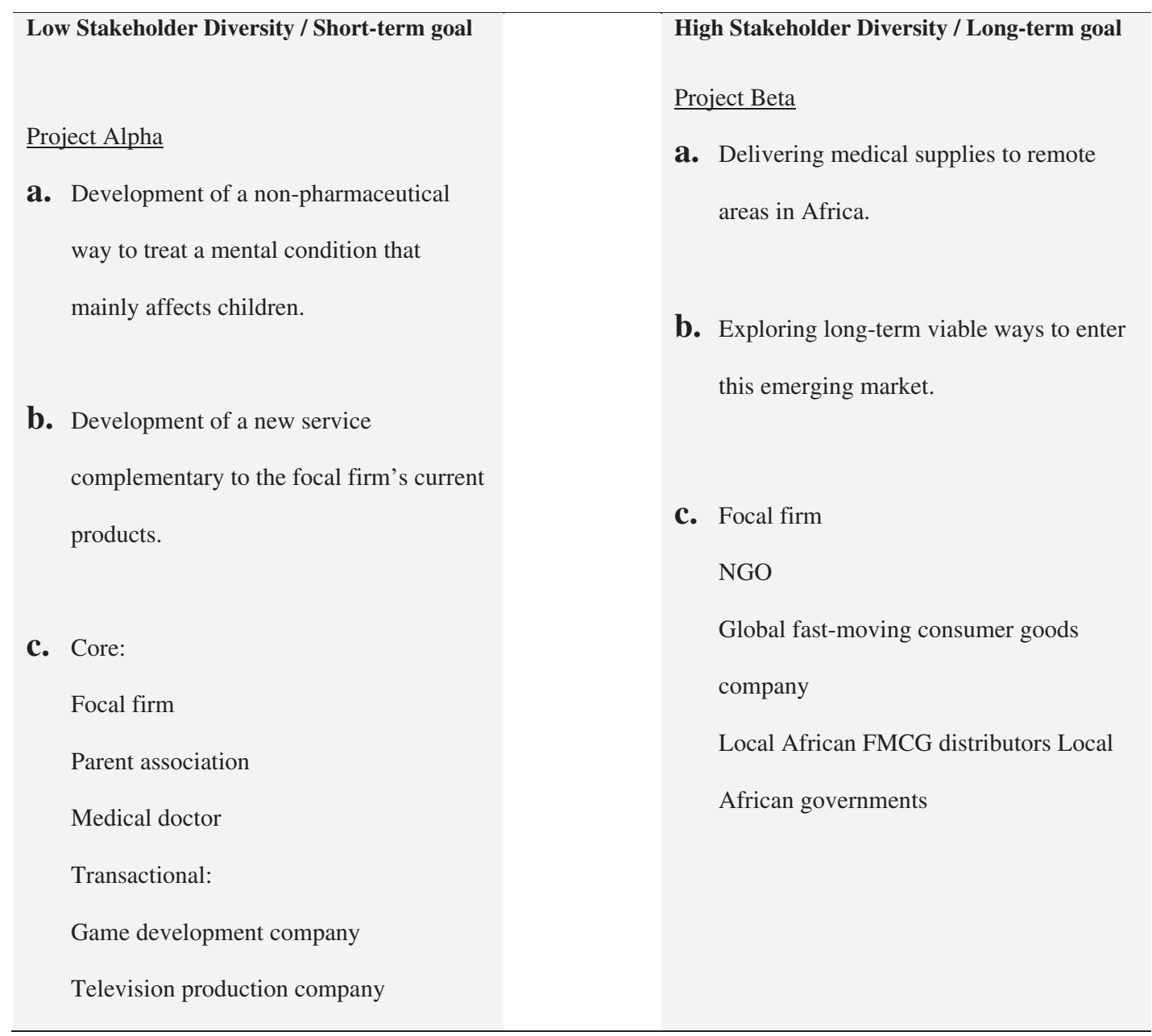

Fig. 2. Case study research design. Key: a. Project content, b. Focal firm objective, c. Stakeholders involved.

provide access to information (Coviello \& Joseph, 2012). We communicated the general theme of our research to each interviewee but did not specify the selected dimensions, to minimize response bias. All interviews were recorded, with the interviewees' consent. Because of the exploratory nature of our research, we used semi-structured interviews with open-ended questions. The semi-structured interview guides reflected the themes we had developed in our tentative framework.

Third, we then engaged in iterative coding of the data sources. This implies that our initial coding scheme was based on the a priori framework, but then evolved through confronting theory with next empirical data (Dubois \& Gadde, 2002). Fourth, we redirected our empirical search by conducting additional interviews, document searches and feedback sessions with managers on our finding. As such, our interview guide with open-ended questions evolved from 30 to 42 topics. This four-step iterative process continued until theoretical saturation was reached (Shah \& Corley, 2006).

\section{Results}

The analysis first reviews how valuable knowledge for the firm emerges through these stakeholder co-creation projects. Then, we discuss specific challenges presented by the involvement of a diverse set of stakeholders during the innovation process. Subsequently, we discuss four specific capabilities and their microfoundations that may address such challenges and strengthen a firm's co-creation efforts. The insights gained from this analysis are summarized in our framework of stakeholder co-creation capabilities (Fig. 3).

\subsection{Co-creation of valuable exploitative and exploratory knowledge through stakeholder co-creation}

The case data reveals that stakeholder co-creation uniquely contributes to the creation of exploitative- and exploratory knowledge for the lead firm. Successful firms balance exploitation and exploration strategies (March, 1991), because product innovation requires the exploitation of existing product innovation competences and the simultaneous acquisition of new capabilities for product innovation (Harrison et al., 2010). The types of knowledge that emerge through both stakeholder co-creation projects was exploitative as well as exploratory in nature. This is surprising as many managers saw these types of projects with diverse external stakeholders as a way to build up novel knowledge which was not related to current business. Yet, our analysis shows that both exploitative and exploratory knowledge emerge simultaneously in both projects. As D2 explains:

Business-wise, we want to stimulate bottom-up innovation in order to create value. This is certainly the goal of our center. Our hope is to look back in 3 to 5 years, to see that we created new business. And also we want to have new insights in what it means to work with a wider range of stakeholders and what kind of business model we 
Table 1

A-priori constructs from extant literature.

\begin{tabular}{|c|c|c|}
\hline Type of construct & Description & Authors \\
\hline Market sensing capability & $\begin{array}{l}\text { A firm's ability to collect and act on information about customer } \\
\text { needs and the influence of technology, competition and other } \\
\text { environmental forces. Market sensing capability still positions } \\
\text { customers as the most focal group of stakeholders. }\end{array}$ & $\begin{array}{l}\text { Day }(1994,2011) ; \text { Krasnikov } \\
\text { and Jayachandran (2008) }\end{array}$ \\
\hline Networking capability & $\begin{array}{l}\text { Networking capability is a firm's ability to attract, interact and } \\
\text { communicate with certain stakeholders to consider engaging in an } \\
\text { innovation project with the lead firm. }\end{array}$ & Perks and Moxey (2011) \\
\hline Relational capability & $\begin{array}{l}\text { Relational capability is defined as a firm's ability to create and } \\
\text { manage its network. The impact of a firm's ability to manage its } \\
\text { network on its innovative capability has been a key research focus in } \\
\text { recent years. Most of this research however focuses on a firm's } \\
\text { relationships with other firms thus ignoring multiple categories of } \\
\text { other stakeholders. }\end{array}$ & Ahuja (2000); Capaldo (2007) \\
\hline Absorptive capacity & $\begin{array}{l}\text { Absorptive capacity is a firm's ability to recognize the value of new, } \\
\text { external information, assimilate it, and apply it to commercial ends. } \\
\text { Research in absorptive capacity so far, has not considered the } \\
\text { particularities of absorbing knowledge from projects that bring } \\
\text { together a multitude of stakeholders. }\end{array}$ & $\begin{array}{l}\text { Cohen and Levinthal (1990); } \\
\text { Spithoven et al. (2011) }\end{array}$ \\
\hline Market learning & $\begin{array}{l}\text { Market learning stems from the knowledge-based view of the firm } \\
\text { and is considered as an important source of competitive advantage. } \\
\text { One of the main benefits of engaging in co-creation projects with } \\
\text { customers is the fact that it enables firms to identify latent needs of } \\
\text { customers. }\end{array}$ & $\begin{array}{l}\text { Brugmann and Prahalad (2007); } \\
\text { Grant (1996); Mahr et al. (2014) }\end{array}$ \\
\hline Market experimentation & $\begin{array}{l}\text { Market experimentation refers to small projects in which a firm } \\
\text { engages, in order to explore new possibilities in increasingly } \\
\text { complex external environments. These small market experiments } \\
\text { are a way to do quick tests and eliminate strategic dead ends early in } \\
\text { the development process. }\end{array}$ & Day (2011) \\
\hline
\end{tabular}

need to create value with external parties. So we see this as a test to try out business models in concurrence with our current business. Concurrently, because of these activities, we see that our people are getting back in touch with their current markets through interacting with patients or patient organizations.

D5 also offers insight in the link between these exploratory cocreation activities and the focal firm's day to day operations:

Creating new business is possible, yet not necessary. Often an important outcome is advancing certain technologies which allow us to have a quicker development in our own business. So the added value lies in the indirect impact on our own business.

This empirical observation links back to the argument made by Grant and Baden-Fuller (2004), that explorative knowledge generation leads to the application of exploitative knowledge in the case of complex goods or services. Reviewing the knowledge creation process in more detail also reveals that the knowledge created in these projects was indeed unique in a way that it could not have been obtained without the involvement of specific external stakeholders.

\subsubsection{Stakeholders as sources of unique information}

By collaborating with a parent association and doctors, the focal firm was able to learn a significant amount about patients. As M1 testifies:

I thought I could go to our internal people to learn about the learning goals of these children. However, to my surprise, our people in research did not know anything about this. So, I had to look externally. Here we ran into a problem again. As a pharmaceutical company we cannot have patient data. Therefore, bringing in an external partner can help us to collect this data anonymously.

M1 went on to explain that through collaborating with the parent organization and doctor, she was able to gain insight into the specific areas where the firm's pharmaceutical products did not suffice. These insights were generated by learning about the typical behavior of these children and any other non-clinical responses. This helped her in laying out the blueprint of what this game needed to achieve. Such unique information would have not been accessible without the collaboration of these intermediaries positioned between the firm and the patient.

Thus, external stakeholders can indeed be considered as valuable knowledge resources for a firm (Garcia-Castro \& Aguilera, 2015). By co-

Table 2

Interviews conducted.

\begin{tabular}{|c|c|c|c|c|}
\hline Project & Interviewee identifier & Job title & Function & Number of interviews \\
\hline \multirow[t]{5}{*}{ A } & D1 & Director & Director, new venturing & 3 \\
\hline & M1 & Project Manager & Manager, project alpha & 1 \\
\hline & D2 & Director & Director, change management & 2 \\
\hline & D5 & Director & Director, outside-in innovation & 1 \\
\hline & D3 & Director & Financial Director, international IT & 1 \\
\hline \multirow[t]{7}{*}{ B } & D1 & Director & Director, new venturing & 2 \\
\hline & D4 & Director & IT Director/Manager, project beta & 1 \\
\hline & N1 & NGO CEO & Founder and CEO & 1 \\
\hline & N2 & NGO Member & Business Development Director & 1 \\
\hline & D2 & Director & Director, change management & 1 \\
\hline & D5 & Campus Manager & Director, outside-in innovation & 1 \\
\hline & $\mathrm{L} 1$ & Logistics Manager & Supply chain optimization & 1 \\
\hline Total & & & & 16 \\
\hline
\end{tabular}




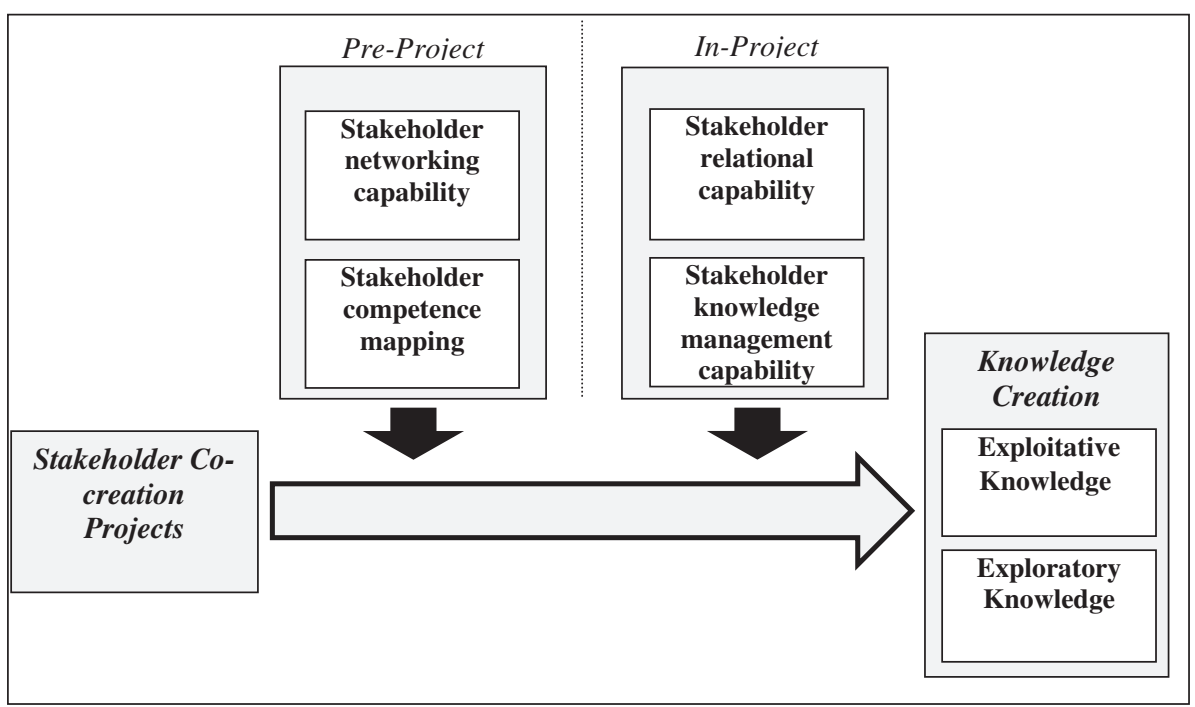

Fig. 3. Conceptual framework.

creating with these specific stakeholders, a firm can gain access to very specific resources that would be otherwise unattainable. Even if a firm has the financial assets to invest in a wide range of resources, some resources are not readily available through market transactions (Gulati, 1999). Access to such resources during the innovation process aids in building up exploitative and exploratory knowledge.

\subsubsection{Stakeholder co-creation as knowledge resource combinations}

Different types of stakeholders may provide firms with unique information. However, this only represents part of the value created by including multiple stakeholders during the innovation process. Indeed, the specific combination of different stakeholders simultaneously creates unique value, as D1 states:

How I see it, is that a final step in our opening up process, is that we share resources with external stakeholders, in a way that we create things that would be impossible without all parties being involved.

Such an alliance, creating value that would be otherwise impossible, was indeed the case in project Beta. As D1 elaborated:

One of our most interesting projects is project Beta. Here, we made a unique combination in that we know a lot about medicine, but not about the market in Africa. The NGO knew the market in Africa, but did not have the resources to start something on their own. The FMCG firm had a logistics chain in place, with room to spare.

Thus, project Beta could not possibly be initiated without all these stakeholders involved. In a later stage, multiple stakeholders in Africa became involved to execute the project's pilot phase. This illustrates that rather than having access to specific resources from one external stakeholder, stakeholder co-creation creates opportunities to combine various resources from a set of stakeholders. Such resource combinations create valuable knowledge for the focal firm and such knowledge is not possible to generate through internal paths or by collaborating with one type of stakeholder only. Director D5 wanted to stress this point and also explained this through an example of another cocreation project with multiple stakeholders, that was not under the specific scope of this study:

For our imaging research, we initially had a service arrangement with two separate universities to do our imaging tests. We had only a few hours a month to use their material for our research. This created a bottleneck. Yet, doing this in-house would cost an enormous amount of money. So we decided to combine the resources of ourselves, a university and a hospital to build a new imaging center. In a next step a large electronics manufacturer will also be included. This gives us not only more capacity but also an opportunity to create unique knowledge.

\subsubsection{Stakeholder co-creation projects as unique contexts for knowledge creation}

Stakeholder co-creation projects were not part of the focal firm's employee's typical day job. Consequently, these projects created a unique context to work in for the firm's employees. As D4 testified when asking about his experience with the start of project Beta:

This was one of these more radical ideas which you cannot carry out within your normal department or business unit. The kind of ideas that people would not look at within their existing roles and routines. If they were possible to execute within our existing departments, we would have already done so. Typically these are things which are costly, far removed from our day job, real innovations.

Such departure from internal employees' day to day job created a context in which employees felt free to pursue opportunities. Multiple sources inform us that as a result, within these projects, people are more willing to contribute ideas and generate new knowledge for the firm. As D5 explained:

An important outcome is the fact that after participating in the project, our internal people have broadened their internal network, have a better idea of what is going on within and outside the company, and are less afraid to reach across business unit borders to collaborate and learn.

In addition, D2 explained:

An important outcome of these projects was to give employees, management and collaboraters the feeling that they can still take initiative, and that this will be appreciated. I think this can revamp the 'innovative spirit' that we inherited from our founder.

Project Alpha indeed managed to influence the internal participants in such a way that it drove their motivation to think about improving current or future business of the focal firm. As M1 elaborated:

We started our initial idea because we wanted to do something new after being through a lot of reorganizations and getting a little burned-out. Throughout the process, we became more and more 
enthusiastic about developing this into a new product. We did not want to let it go anymore.

Thus, a third aspect that makes these types of projects valuable contributors to knowledge creation, is that they create unique contexts for knowledge generation that drive creativity from external stakeholders as well as internal employees. Through immersing a team of people in such a context, outside of their regular day to day schedule, these teams appear to become more creative and original in their ideation.

In sum, stakeholder co-creation created valuable knowledge for the focal firm through privileged access to information through stakeholders; unique resource combinations; unique contexts for knowledge creation. As such, both cases provide tangible evidence that the simultaneous involvement of multiple stakeholders, creates unique value, which is not possible to attain through unilateral co-creation with one type of stakeholder.

\subsection{Challenges in engaging multiple stakeholders during the innovation process}

The analysis of our case study materials also yields interesting results with regard to the specific challenges that a lead firm may face when cocreating with multiple stakeholders simultaneously. The main challenges lie in: finding and engaging the appropriate stakeholders for co-creation; conflict stemming from stakeholder diversity; and management of stakeholder co-created knowledge.

First, when a focal firm decides they want to increasingly collaborate with external stakeholders, such collaboration cannot take place without finding the appropriate stakeholders with whom to collaborate. In today's increasingly connected society, such a search for partners would seem relatively easy, yet during our case study analysis, it became apparent that this presented a serious challenge for the focal firm. As M1 testifies when speaking about finding the right partners to develop her initial idea of project Alpha:

The search for external partners. This is where I have the feeling that we did not do enough initial scouting of our external environment. We were doing this project during 6 months, before and after work, during the weekends... So we did not have the time to really do a proper scouting of our external environment. We should have done more research. Take the doctor that was involved. We are completely linked to his ideas now. Maybe there are others out there with different ideas.

Thus, identifying the right stakeholders to collaborate with is a challenging task for a focal firm. The multiple stakeholder context complicates this task further. Indeed, knowing where specific competences are present within your competitors (i.e. one stakeholder type); is more easy for a firm than producing an overview of the competences of different types of stakeholders. Stakeholders such as patients, consumer groups and NGO's often do not have formal structures and are therefore more difficult to analyze. In the same vein, multiple stakeholders that become more empowered to contribute to the innovation process, may choose to do so or not. Indeed, as external stakeholder N2 exemplifies when asked about the start of project Beta:

Being just the two of us and this project being the thing that we gave up our whole life for, we weren't prepared to compromise too far on what the project was. Basically we are committed to work on the idea, so if we would collaborate, we really needed to know what it is we would get into. Otherwise there are too many unknowns to start a project. In the beginning, there wasn't enough communication for everybody to understand this.

Motivating different stakeholder types to collaborate with the firm simultaneously is more complex than doing this for one stakeholder type such as consumers (Hoyer et al., 2010). Indeed, even before the project starts, conflicting views need to be harmonized, or else some stakeholders may not start the project.

Second, the specific diversity in project teams created by the inclusion of multiple types of stakeholders may create conflict with regard to the intended goals of such projects, as well as in the execution of the co-creation process. As L1 describes:

Absolutely, I think this was one of the main issues, we did not speak the same language and did not have the same underlying beliefs/ principles. If you look at us, we are a company that wants to impact people's lives, which is important, we want to make people's life better. However we want to do this in an economically realistic perspective. We have to be able to make a profit. However, from an NGO perspective, they did not look at profitability, they were all about reaching people and the rest was not important and they had trouble understanding why these other goals (profit) were important. This was a very different approach and this made discussion quite difficult because they were different people with different values.

Thus, different stakeholder types may speak the same language, yet still have a very different way of expressing themselves. Consequently, our case study analysis shows evidence of the theoretical assumption that bringing together multiple stakeholder types comes with increased divergence in communication styles as well as goals and interests (Donaldson \& Preston, 1995).

With regard to intended outcomes, the diversity of stakeholders involved in these projects caused conflict as well. Surprisingly, this conflict even ran between persons that were from the same firm, yet from a different business unit. Both projects showed such internal conflict, D4 testifies about project Beta and M1 about project Alpha.

The start wasn't always that easy, mainly because it was a project with persons starting with different ideas. $X$ and $Y$ saw the project as a purely 'Aid' project, while $Z$ saw it as a commercial project with the goal of making a profit in the mid-long term. So the base of the project had a conflict. As a result, we could not move on because we did not know how to combine our ideas. Even internally, this can be quite hard because everyone starts out with their respective own idea and goals, which they have to bring together and then make sure that everyone is behind it. This was very clear in our initial team, after the first session, two people dropped out and said they were not willing to carry on with the project.

A third challenge specifically emerging from stakeholder co-creation projects is capturing the wide range of knowledge that is created in such projects. Several interviewees across projects indicated that this was an important challenge to deal with. M1 and N2 stated:

I think this is because of the fact that we are still young in the field of innovation, not scientific innovation but innovation in terms of services. This external innovation is new to us. And I notice, that a lot of information is stored in people's minds. I share everything with the project team and my director. But I do not write this down, it's more a networking thing.

I think if you are going to put together such an unlikely collaboration, it is very useful to have a kind of trusted third party. This partner shouldn't have a corporate agenda, but should do facilitation, listening, and interpreting information from one partner to another.

Thus, when different stakeholders are involved, existing capabilities to capture knowledge do not appear to suffice. The reason for this lies in the fact that external stakeholders may not be used to work in a corporate context and thus may not be familiar with ways to explicate and disseminate knowledge generated. In sum, these multilateral interactions between the firm and the different stakeholders involved, create 
new challenges that cannot be addressed with extant capabilities. Therefore, to successfully manage these types of collaborations, a lead firm may have to develop a different set of capabilities (Driessen \& Hillebrand, 2013).

\subsection{Stakeholder co-creation capabilities}

After identifying how knowledge emerges from stakeholder cocreation, and the specific challenges that exist in such collaborations, our analysis focused on identifying capabilities that address these challenges. In doing so, these capabilities strengthen a firm's co-creation activities. This section is organized according to two distinct phases where a need for stakeholder co-creation capabilities emerged: 1) before a project starts and 2) during a stakeholder co-creation project. Indeed, systematic analysis of our case study materials revealed that, in the case of stakeholder co-creation, there is a specific need for capabilities that lay the groundwork before a project starts (Mitrega, Forkmann, Ramos, \& Henneberg, 2012).

These dimensions link close to Zahra and George's (2002) distinction between potential and realized absorptive capacity. Yet, we are specifically interested in those capabilities underlying absorptive capacity that aid in stakeholder co-creation. Accordingly, in the specific context of stakeholder co-creation, we conceptualize two categories of cocreation capabilities (Bierly et al., 2009). Within both categories, we identify two specific capabilities that strengthen a firm's ability to manage co-creation projects in such a way that they create valuable knowledge for the lead firm. Furthermore, our case study setting allowed for an in-depth examination of the microfoundations of each capability. We present examples of each capability's microfoundational routines. These examples do not intend to be exhaustive, as they may differ between organizations and industries (Ethiraj, Kale, Krishnan, \& Singh, 2005), but rather illustrate how capabilities are tangibly expressed in organizations (Lewin et al., 2011).

\subsubsection{Pre-project stakeholder co-creation capabilities}

Through systematically combining exiting literature and our case study material, two specific capabilities emerged that may aid a firm in laying the groundwork for stakeholder co-creation projects. As such, they are capabilities that influence the eventual outcome of projects even though they are deployed before projects actually take place. These capabilities are stakeholder networking capability and stakeholder competence mapping.

The first pre-project capability we identify is a firm's stakeholder networking capability. This capability reflects a firm's ability to find and attract the appropriate stakeholders for co-creation activities. Analysis of our case study data led us to conclude that existing work on a firm's networking capability does not sufficiently accommodate challenges engendered by stakeholder co-creation. For example, Mitrega et al. (2012) define networking capability as a combination of relationship initiation, relationship development and relationship termination. Yet, those specific components do not accommodate some of the specific challenges created by networking with a diverse range of stakeholders. For example, Mitrega et al. (2012) discuss the attraction of valuable companies as business partners. However, our case study clearly indicates that finding and attracting valuable stakeholders for co-creation, that are not necessarily companies, required a more elaborate type of networking capability. This accommodates the specific challenges in engaging stakeholders for co-creation, such as distrust of corporations or non-financial goals. D5 had a good overview of previous co-creation projects that failed before the project even started because of a lack of such an expanded capability:

I see three areas where things went wrong before. First, we had a situation where we were talking to one external partner, yet what we did not know was that another department of our firm was speaking to this external stakeholder's direct competitor. You can imagine that this was of course a problem. Here we learned that we needed to have a good overview of this.

We also had a situation where we put our biologists together with people from electronics manufacturers. We had to stop this, because in the initial phase it became immediately clear that these people could not talk to each other. If I am honest, more than once, I was embarrassed because we were in talks with a potential partner and it clearly showed that our internal people were not ready.

A third issue is that our internal people have the tendency to walk over smaller stakeholders in initial talks. So it is important to make sure that these external smaller stakeholders are represented well and their needs understood before a project starts. What I learned from this, is that we need to prepare with our internal departments first before we can go out and talk to external stakeholders. And now I haven't even talked about what happens when a project actually starts!

Additional interviews with other firm employees across projects substantiated this need for a strong stakeholder networking capability. For example, D2 who had to fulfill a mediation role when there was conflict in project Beta, reflected back on what could have avoided this conflict:

We should avoid that a team meets each other face-to-face only when they start working on a project. This makes sense, people need to have a phase to get to know each other first. We are programmed like that. We need to go through a phase to know who somebody is. Can we trust them? Are you with me or against me? Are you going to stab me in the back? Can I trust you in keeping secrets? Can you create value for me? A lot of things come to mind. Especially with diverse external stakeholders, we noticed that these first contacts should not be virtual.

In addition, some obstacles to stakeholder co-creation may lie in the specific reputation a firm or an industry has. For example M1 talked about the fact that some children's television companies did not want to talk to her in relation to project Alpha:

This is something we came across quite often, they do not want to see their name linked to a pharmaceutical company. This is really an impediment in our search for external partners. We had this before when we went to speak to doctors for example, especially in country X, in my own country this is a bit better, but in country X, our industry has a bad name. So when I try to speak with people there, there is immediate resistance. In the end, they agreed on talking with us on a consultancy basis for this project specifically, but they did not want to go in a long going co-creation effort.

Stakeholder networking capability is composed of a complex bundle of routines and individual skills. For example, our case study suggests that as a large firm, it is difficult to communicate in one voice concerning your goals related to innovation. Failing to do this, in turn results in certain stakeholders not trusting the lead firm and hence rejecting a collaborative relationship. Furthermore, as these stakeholders are not always organizations with a profit-maximizing goal, firms need to approach these stakeholders in different ways than they would in a traditional partnership between firms. Otherwise, some stakeholders would see no value in potential co-creation activities with the lead firm (Bridoux \& Stoelhorst, 2013). An exemplary overview of skills and routines that underlie this capability appears in Table 3.

The second capability identified as crucial to lay the groundwork for stakeholder co-creation is stakeholder competence mapping. This capability is a firm's ability to produce an explicit overview of the different competences present in each of its different stakeholders. When firms solely engage with one type of stakeholder, competences of partners 
Table 3

Stakeholder networking capability microfoundations.

\begin{tabular}{|c|c|c|}
\hline Capability & Microfoundations & \\
\hline \multirow[t]{2}{*}{ Stakeholder networking } & Routines & $\begin{array}{l}\text { Communicating consistently about innovation partner selection criteria } \\
\text { Communicating consistently about the types of collaboration partners needed } \\
\text { Engaging in networking opportunities (e.g. industry roundtables, conferences, ..) } \\
\text { within different stakeholders' networks }\end{array}$ \\
\hline & Individual skills & $\begin{array}{l}\text { Employee networking skills } \\
\text { Individual employee networks }\end{array}$ \\
\hline
\end{tabular}

are easily recognizable. Yet, when a stakeholder is far removed from the focal firm's current business, this is more challenging. D1, who oversees different types of stakeholder co-creation projects of our focal firm, identified this as a crucial skill they need to develop:

Seeing what we can do together with these types of stakeholders is challenging. I can give you an example. We are looking for opportunities with an electronics manufacturer to co-develop a medical device that can help consumers track their behavior and also dispense medicine. However, knowing what this electronics manufacturer can do and what they are talking about is fundamentally different than what we are used to when talking to people in our industry.

In practice, this was the case in project Alpha. Indeed, M1 was disappointed that she did not have a good overview of what some stakeholders, far removed from her daily job, could do, and whether they were on top of their field:

Searching for the right external competences was key. We should have paid more attention to this. So we did not have the time to really do a proper scouting of our external environment. Take for example our game developer, we met him through a mutual contact and then decided to go with him. Yet for me, this remains an important question, do we have the right partner? What do I know about gaming companies?

Thus, our focal firm had learned through experience that such an overview of potential partners is of importance and had already taken the first steps to develop routines in doing so. Therefore, a firm's ability to structurally map the competences of their various stakeholders strengthens the potential of stakeholder co-creation projects to create valuable knowledge. Indeed, if stakeholders are unique knowledge sources that need to be combined to create knowledge (Garcia-Castro \& Aguilera, 2015), a firm first needs to know what the actual competences of each of these knowledge sources are. We note that this capability assumes that a focal firm has a clear overview of its own competences. Yet, firms may differ in their ability to produce an overview of their own internal competences. Such a capability to map a focal firm's internal competences is required to match multiple stakeholders' competences to the focal firm's internal competences. As this capability is not specific to the context of stakeholder co-creation, it is not within the scope of the current study, yet extant work provides relevant guidelines (Pablo, Reay, Dewald, \& Casebeer, 2007; Vorhies \& Morgan, 2005).

Producing a clear overview of the competences an external stakeholder possesses, requires a multitude of routines that underlie this capability. For example, data from several interviews in our focal firm suggest that the organization of regular exploratory meetings with different types of stakeholders is a routine that enables the firm to constantly monitor what the firm's different stakeholders' current level of competences is in areas where the focal firm needed complementary competences. Such activities also need to be complemented with the internal dissemination of this information. Furthermore, stakeholder competence mapping requires persons within the focal firm with knowledge of specific stakeholders' inner workings. For example, persons who have previously worked for an NGO or former academics may act as gatekeepers between the firm and these stakeholders. Table 4 gives an exemplary overview of such microfoundations.

\subsubsection{In-project stakeholder co-creation capabilities}

In-project stakeholder co-creation capabilities relate to the capabilities that enable a firm to deal with the specific challenges of stakeholder co-creation. They do this in such a way that they strengthen the ability of a firm to generate valuable knowledge from these types of collaborations. Analysis of our case study data and systematically combining with existing literature resulted in the identification of two specific capabilities: stakeholder relationship management and stakeholder knowledge management.

"Stakeholder relational capability" implies a lead firm's ability to manage its relationships with a multitude of stakeholders in an ongoing co-creation project, as well as the relationships of those stakeholders with one another. Extant literature informs us about a relationship capability between firms (Capaldo, 2007; Lorenzoni \& Lipparini, 1999). Yet, these existing capabilities may not suffice in the stakeholder cocreation context. The reason is that these capabilities typically look at relationships that are (1) dyadic and (2) inter-organizational. Across materials in our case study, it became apparent however that a lead firm needs to concern itself with more than its dyadic ties. Indeed, when multiple stakeholders are involved, these stakeholders also need to have a positive relationship with each other. For example, when talking about some of the friction going on in project Beta, D2 talked about how this caused concern:

There was a big concern of the NGO members, that these two big American companies would start discussing without them on a higher level and leave them out. Or that they would become just a little pawn while it was their initial idea, which grew from their experience in Africa.

So this required D2 to convince the NGO not only of the goals of the focal firm but also of the other stakeholders involved, such as the FMCG firm. Indeed, collaborations are more difficult to manage when the

Table 4

Stakeholder competence mapping microfoundations.

\begin{tabular}{|c|c|c|}
\hline Capability & Microfoundations & \\
\hline \multirow[t]{5}{*}{ Stakeholder competence mapping } & Routines & Regularly conducting explorative meetings with stakeholders \\
\hline & & Documenting stakeholder competence assessment explicitly \\
\hline & & Disseminating stakeholder competence assessment internally \\
\hline & Individual skills & Personal mandate as first line of communication with different stakeholder \\
\hline & & $\begin{array}{l}\text { organizations' gatekeepers } \\
\text { Knowledge of stakeholder organizations' inner workings }\end{array}$ \\
\hline
\end{tabular}


interests, goals, and practices of the various actors differ (O'Mahony \& Bechky, 2008), as is typically the case in stakeholder co-creation projects as opposed to interorganizational co-creation projects. Indeed, the interorganizational nature of relationships considered in current relational capability literature neglect specific challenges of stakeholder co-creation. For example, trust building between organizations requires fundamentally different routines than trust building between a firm and consumers or other stakeholders (Capaldo, 2007; Driessen \& Hillebrand, 2013; Singh \& Sirdeshmukh, 2000). Our case study data indicate that because a multitude of stakeholders are involved, the lead firm needs a more extensive relational capability than would be required in a traditional network alliance of similar firms. Indeed, D4 illustrated that some of the frictions that existed specifically related to the multiple stakeholder context:

Let me talk about friction. On the one hand you have a group of people, who almost think dogmatically, and I don't want to sound too negative, the NGO's goal is very clear, they want to lessen child mortality. This is a very specific goal and they were very focused on that. Everything was directed towards getting those products to a specific group of people and doing this in collaboration with the FMCG's distribution network. From their perspective it was not necessary to make this commercially viable. For them it was important to get the products there, how it happened did not matter. They were already working on this for years and had it stuck in their minds. This tension always remained throughout the project, even until the try-out presentation where we were really thinking of quitting.

The stakeholder relational capability has a complex bundle of underlying routines and individual skills. Illustrations of such microfoundations in our case context can be found in Table 5. Several microfoundations of this capability relate to building trust, a concept well described within team literature (De Jong \& Elfring, 2010; Molina-Morales, Martínez-Fernández, \& Torlò, 2011).

Stakeholder knowledge management refers to a firm's ability to capture and explicate all relevant knowledge generated during stakeholder co-creation activities. This entails not only the knowledge generated in interaction between the focal firm and specific stakeholders, but also knowledge generated by interaction among stakeholders. Absorptive capacity theorizing has noted that external knowledge can be retained through maintaining inter-organizational relationships (Spithoven, Clarysse, \& Knockaert, 2011). Yet, in the case of stakeholder cocreation, we argue that such external retention of knowledge is less applicable. The reasoning is that firms collaborate with a wide range of stakeholders across different projects and activities. These stakeholders may all have different structures and cultures. Some of them are even not formal organizations, such as temporary activist groups. Therefore, relying on these relationships with these stakeholders to retain cocreated knowledge is not optimal. Consequently, firms benefit from the explicit codification and dissemination of knowledge co-created with multiple stakeholders.
Second, when firms include multiple stakeholders simultaneously in their innovation activities, knowledge is also created between multiple stakeholders interacting with each other. Indeed unique knowledge results from interactions among specific combinations of parties (Nonaka \& Takeuchi, 1995). If one of a set of complementary stakeholders halts its involvement in the project, knowledge thus may disappear. As a result, firms need to be able to explicitly capture this knowledge created in interaction between the different stakeholders with whom they cocreate. As a project manager M1 of project Alpha clarified, when asked about the outcomes of project Alpha, "Our idea is to get the information that is generated in this project back to our research department to improve the products they are currently working on."

However, during our analysis of the case study, it also became apparent that not every focal firm employee agreed on the specific routines that would enable such a knowledge management capability. For example, when talking about ways to disseminate the knowledge generated in stakeholder co-creation projects with D1, overseeing multiple projects, D1 wanted to capture such knowledge electronically:

We are trying to set up an internal platform to make sure that the things that we pick up out of stakeholder co-creation projects are noted down somewhere so that if needed, people can make advantage of these connections at a certain point.

Yet, M1 explained that such an initiative does not work when talking to many different external stakeholders:

A database, I have seen a lot of initiatives like this, however, these often die a silent death. This is because this is against human nature, if I know that I need to write up reports after a project, I would hold back some information in order to avoid the hassle of writing up these reports. I believe more in networks like LinkedIn where everyone sees which knowledge can be accessed through our network so maybe we should work with these kinds of tools.

While the interview data and extant work show that the exact operationalization of a stakeholder knowledge management capability (e.g. the use of databases) is context-dependent (Ethiraj et al., 2005), we converge on the finding that a strong knowledge management capability, tailored at accommodating different communication styles and stakeholder cultures, was needed to capture the specific knowledge generated with unusual combinations of collaboration partners.

Stakeholder knowledge management capability consists of routines and individual actions that clearly capture and disseminate what is learned during a stakeholder co-creation project. These routines include information sharing routines between the actors involved in the project and internal information sharing within the focal company with other business units Additionally, extant literature also points to incentives for knowledge identification and dissemination (Foss, Laursen, \& Pedersen, 2011) as important microfoundations of this capability. Table 6 offers exemplary microfoundations of this capability.

Table 5

Stakeholder relational capability microfoundations.

\begin{tabular}{|c|c|c|}
\hline Capability & Microfoundations & \\
\hline \multirow[t]{9}{*}{ Stakeholder relational } & Routines & Investing in the buildup of specific stakeholder relationships \\
\hline & & Trust building activities \\
\hline & & Goal identification exercises \\
\hline & & Conflict management routines \\
\hline & & Assigning key contacts within the firm (gatekeepers) \\
\hline & & Top management resource allocation for co-creation activities (team members are dedicated to project) \\
\hline & & Preparing internal workforce for openness \\
\hline & Individual skills & Investing in employees with relationship building skills \\
\hline & & Openness for informal encounters with external stakeholders \\
\hline
\end{tabular}


Table 6

Stakeholder knowledge management capability microfoundations.

\begin{tabular}{|c|c|c|}
\hline Capability & Microfoundations & \\
\hline \multirow[t]{3}{*}{ Stakeholder knowledge management } & Routines & Information sharing routines within co-creation network \\
\hline & & $\begin{array}{l}\text { Internal information sharing within lead company with other business units } \\
\text { Incentives for knowledge identification and dissemination }\end{array}$ \\
\hline & Individual skills & Employee-level absorptive capacity \\
\hline
\end{tabular}

\section{Discussion}

This study examines how a focal firm creates valuable knowledge with a wide range of stakeholders, the specific challenges that emerge and the capabilities needed to address such challenges. The purpose of this study was to confront extant theory with an empirical case in order to advance insights for theory and practice. This study has done so in several ways.

\subsection{Theoretical implications}

First, despite its importance, stakeholder co-creation during the innovation process remains significantly under-theorized in current literature (Hult, Mena, Ferrell, \& Ferrell, 2011). Yet, a recent spike in interest from practice in the phenomenon motivated us to examine such stakeholder co-creation from an in-depth case study perspective. Our case study is indeed aligned with the view that organizations create value through an interdependent web of social relationships (Hult et al., 2011; Vargo \& Lusch, 2008). We enrich this view by specifically examining co-creation among multiple stakeholders simultaneously during the innovation process. Indeed, different types of stakeholders are valuable knowledge sources that can be configured in such a way that they create valuable knowledge for the firm. Concurrently, we inform current literature on co-creation during the innovation process (Hoyer et al., 2010; Mahr et al., 2014; Menguc et al., 2014), and show compelling evidence that stakeholder co-creation requires new capabilities to manage the challenges they present. In doing so, we address a standing call for more insight in how companies use a multitude of external sources to create knowledge during the innovation process, and consequently adapt to changes in their environment (Harrison et al., 2010; MSI, 2014). More specifically, we respond to calls for an in-depth exploration of how firms can facilitate active participation of nonmarket stakeholders during the innovation process (Coviello \& Joseph, 2012; Driessen \& Hillebrand, 2013). Consequently, this study lays the groundwork for further quantitative research into such collaborations.

Second, as these types of co-creation projects create unique challenges for the focal firm because of the specific types of actors involved, our study investigates the capabilities required to manage these challenges. Previous research has tended to study the link between a firm's network of collaboration partners and performance. Yet, such research typically does not address the capabilities required to strengthen the link between co-creation during the innovation process and performance (Harrison et al., 2010; Laursen \& Salter, 2006). Such capabilities are particularly relevant in a context where a firm's innovation network consists of multiple types of stakeholders. For example, our results show, that without a firm's ability to attract specific stakeholders to their innovation projects, such projects cannot even take place. This is fundamentally different from a context where all stakeholders are profit-maximizing firms. From an RBV perspective, stakeholder cocreation capabilities are thus what is needed for a lead firm to deploy their unique knowledge sources (i.e. stakeholders) in such a way that they create value for the firm (Grant, 1996; Menguc et al., 2014). Specifically, firms require a stakeholder networking capability and stakeholder competence mapping capability, before a project starts. To manage the socially complex interactions in an ongoing project, with multiple stakeholders, a firm requires a stakeholder relationship management and a stakeholder knowledge management capability. Additionally, we explore the microfoundations of these capabilities. In doing so, we inform theory and practice by creating detailed insight in the abstract notion of capabilities. Indeed, these microfoundations present the idiosyncratic building blocks of the identified stakeholder co-creation capabilities. They are explicit and executable (Felin et al., 2012; Lewin et al., 2011). As such they do not only inform further research (for example as items for quantitative research) but also practice as hands on routines to implement.

Third, the study contributes to extant literature on absorptive capacity by examining the underlying dimensions of absorptive capacity in a stakeholder co-creation context (Harrison et al., 2010). Indeed, scholars have argued that absorptive capacity as a construct is often a black box (Bierly et al., 2009; Lane et al., 2006; Lewin et al., 2011). Therefore, additional insight is necessary into the construct via examining its underlying dimensions. We zoom in on one category of capabilities that underlies absorptive capacity, by examining the capabilities that strengthen a firm's ability to create and capture valuable knowledge from stakeholder co-creation projects. In doing so, we recognize Van Den Bosch et al. (1999), in that such underlying dimensions relate to the specific knowledge context and environment. This implies that we do not claim that these capabilities entirely extend to absorptive capacity in a non-stakeholder co-creation context.

\subsection{Managerial implications}

Stakeholder co-creation challenges the traditional roles of firms and their stakeholders. The findings provide practical lessons for managers that want to increasingly engage in such projects. First, involving an increasing number of different stakeholder types during the innovation process, creates valuable knowledge while simultaneously challenging the lead firm's capability to manage such socially complex partnerships. Therefore, an increasing diversity in stakeholders involved during the innovation process, needs to go hand-in-hand with an increased investment in developing stakeholder co-creation capabilities. This study proposes four such capabilities. The identified microfoundations should provide managers with direct hands-on routines to implement.

Managers should be aware that successful co-creation projects require capabilities to be deployed at multiple points in time. That is, capabilities to find and engage the right stakeholders for co-creation, are important drivers of successful knowledge co-creation. Practically, this translates into routines such as engaging in networking opportunities (e.g., industry roundtables, conferences) across different stakeholder networks or regularly conducting exploratory meetings with stakeholders. Such preemptive management of external stakeholders as potential co-creation partners requires firms to look forward and have a clear view on how and where which types of external stakeholders will be required for their innovation processes. Neglecting to do this may lead a firm to spend too much time and resources on interacting with stakeholders that may not be relevant to their innovation processes.

Finally, this research demonstrates the pivotal impact of partner selection in co-creation. While previously, managers typically needed to be concerned only with technical competences of potential collaborators, the range of variables under consideration becomes broader when multiple stakeholder types are considered. Indeed, with multiple stakeholders involved simultaneously, a firm needs to make sure that it also selects stakeholders that can work with each other. Concurrently, it 
needs the capability to manage conflict that may still arise. In addition, as more stakeholders, removed from a firm's core business, become involved, outside (consumer) perceptions of the collaboration may also need to be considered. For example, our case study hints at the fact that a children's television producer may not want to be seen as innovating with a pharmaceutical firm. Indeed, initial research indicated that consumers do react to the types of stakeholders involved during innovation (Fuchs et al., 2013). This is outside the scope of the current study, yet it provides an interesting research question for research and practice.

\subsection{Limitations and suggestions for research}

As is true for any research project, the research choices created some limitations, some of which offer avenues for further research. First, a critical assumption in this study is the view that a focal firm can manage its network of stakeholders. Indeed, extant literature has presented an interesting debate in recent years concerning network manageability (Van Bockhaven, Matthyssens, \& Vandenbempt, 2013). Some authors take the theoretical stance that networks are emerging and nonmanageable, suggesting that if every actor would shape and manage their own relationships, this would create a paradox that eliminates network development (Ford, 2011). Others reject this view and claim that different capabilities are required to deal with opportunities and challenges presented in different types of networks (Möller et al., 2005). This study follows the latter view.

Second, this study adopts a lead firm perspective, where the focal firm is viewed as the central actor within its innovation network (Dhanasai \& Parkhe, 2006). Further research might investigate the capabilities of the broader network of stakeholders. In particular, it would be valuable to examine the nature and impact of the capabilities of stakeholders that are not organizations in the knowledge creation process. Exploring a "fit" between the capabilities of the various stakeholders involved during the co-creation process would be interesting (Sluyts, Matthyssens, Martens, \& Streukens, 2011). Future research needs to examine collaborations from a multiple-genre perspective, encompassing the interplay between capabilities possessed by the various stakeholders involved during co-creation activities.

In a similar vein, exploring value creation from the perspectives of different stakeholder types may be fruitful. Indeed, during several interviews conducted throughout this study, interviewees also referred to value created for stakeholders other than the focal firm. Non-focal firms might not require similar coordinative capabilities. Besides a stakeholder's status, other elements such as size (Mishra \& Shah, 2009), ownership structure (Hoopes \& Madsen, 2008), or even social class (Hart \& Sharma, 2004) might learn its potential to capture value and required capabilities, which offer interesting paths for further research. However, this step is outside of the scope of the current study.

Additionally, this case study relied on a number of in-depth interviews with key informants, which have been triangulated with other data sources. Future research might include more interviews with more different types of stakeholders that could extend the scope of this work beyond its focus on the focal firm. Nonetheless, the data gathered offers significant insight within the current scope of work.

A combination of various capabilities can create even stronger competitive advantages than the sum of individual capabilities (Barney, 1991). Accordingly, insights in how the configuration of different stakeholder co-creation capabilities, strengthening each other, ultimately influences the success of co-creation projects would be valuable. Similarly, stakeholder co-creation capabilities may interact with existing capabilities within the firm. For example, firms may differ in their ability to produce an overview of their own internal competences. Such a capability to map internal competences may be required to match multiple stakeholders' competences to the focal firm's internal competences. Both these limitations are addressable with a quantitative design that measures the specific impacts of stakeholder co-creation capabilities on knowledge creation and performance.

Finally, this study was conducted in the pharmaceutical industry. Throughout our interviews with both external and internal firm project members, we observed that a firm's industry can influence the link between the capabilities needed to engage in co-creation projects and the knowledge the projects generate. For example, the pharmaceutical industry traditionally has been known for relying on closed innovation processes and imposing strict regulations on contacts with certain stakeholders (e.g., consumers, caregivers). Different innovation norms or regulations in other sectors thus might alter the demand for certain capabilities during co-creation. It was not our goal to present capabilities that are all generalizable across all industries, as those would likely be overly abstract and not conductive to managerial action (Ethiraj et al., 2005). Therefore, investigating stakeholder co-creation capabilities and their outcomes, in different industries represents an important goal for further research (Hult et al., 2011).

\section{Acknowledgments}

The authors thank the editors and two anonymous reviewers for their input and suggestions to improve this study. The authors acknowledge the financial support from the Research Foundation Flanders (FWO).

\section{References}

Abell, P., Felin, T., \& Foss, N. (2008). Building micro-foundations for the routines capabilities, and performance links. Managerial and Decision Economics, 29(6), 489-502.

Agarwal, R., \& Helfat, C.E. (2009). Strategic renewal of organizations. Organization Science 20(2), 281-293.

Ahuja, G. (2000). Collaboration networks, structural holes, and innovation: A longitudinal study. Administrative Science Quarterly, 45(3), 425-455.

Amaldoss, W., \& Rapoport, A. (2005). Collaborative product and market development: Theoretical implications and experimental evidence. Marketing Science, 24(3), 396-414.

Amit, R., \& Schoemaker, P.J. (1993). Strategic assets and organisational rent. Strategic Management Journal, 14(1), 33-46.

Arikan, A.T. (2009). Interfirm knowledge exchanges and the knowledge creation capability of clusters. Academy of Management Review, 34(4), 658-676.

Atuahene-Gima, K. (2005). Resolving the capability-rigidity paradox in new product innovation. Journal of Marketing, 69(4), 61-83.

Barney, J. (1991). Firm resources and sustained competitive advantage. Journal of management, 17(1), 99-120.

Bierly, P.E., Damanpour, F., \& Santoro, M.D. (2009). The application of external knowledge: Organizational conditions for exploration and exploitation. Journal of Management Studies, 46(3), 481-509.

Bridoux, F., \& Stoelhorst, J. (2013). Microfoundations for stakeholder theory: Managing stakeholders with heterogeneous motives. Strategic Management Journal, 35(1), 107-125.

Brugmann, J., \& Prahalad, C.K. (2007). Cocreating business's new social compact. Harvard Business Review, 85(2), 80.

Capaldo, A. (2007). Network structure and innovation: The leveraging of a dual network as a distinctive relational capability. Strategic Management Journal, 28(6), 585-608.

Cepeda, G., \& Vera, D. (2007). Dynamic capabilities and operational capabilities: A knowledge management perspective. Journal of Business Research, 60(5), 426-437.

Cohen, W.M., \& Levinthal, D.A. (1990). Absorptive capacity: a new perspective on learning and innovation. Administrative Science Quarterly, 35(1), 128-152.

Coviello, N.E., \& Joseph, R.M. (2012). Creating major innovations with customers: Insights from small and young technology firms. Journal of Marketing, 76(6), 87-104

Cuccureddu, G. (2011). DHL's open innovation contest and the quest for radical decentralization. (Retrieved October, 11, 2011, from) http://www.innovationmanagement.se/ 2011/10/07/dhl-open-innovation-contest-and-the-quest-for-radical-decentralization/.

Day, G.S. (1994). The capabilities of market-driven organizations. Journal of Marketing, 58(4), 37-52.

Day, G.S. (2011). Closing the marketing capabilities gap. Journal of Marketing, 75(4), $183-195$.

De Jong, B.A., \& Elfring, T. (2010). How does trust affect the performance of ongoing teams? The mediating role of reflexivity, monitoring, and effort. Academy of Management Journal, 53(3), 535-549.

Dhanasai, C., \& Parkhe, A. (2006). Orchestrating innovation networks. Academy of Management Review, 31(3), 659-669.

Donaldson, T., \& Preston, L.E. (1995). The stakeholder theory of the corporation: Concepts, evidence, and implications. Academy of Management Review, 20(1), 65-91.

Driessen, P.H., \& Hillebrand, B. (2013). Integrating multiple stakeholder issues in new product development: An exploration. Journal of Product Innovation Management 30(2), 364-379. 
Driessen, P.H., Kok, R.A.W., \& Hillebrand, B. (2013). Mechanisms for stakeholder integration: Bringing virtual stakeholder dialogue into organizations. Journal of Business Research, 66(9), 1465-1472.

Dubois, A., \& Gadde, L. -E. (2002). Systematic combining: An abductive approach to case research. Journal of Business Research, 55(7), 553-560.

Dubois, A., \& Gadde, L. -E. (2014). "Systematic combining"-A decade later. Journal of Business Research, 67(6), 1277-1284.

Dyer, J.H., \& Singh, H. (1998). The relational view: Cooperative strategy and sources of interorganizational competitive advantage. Academy of Management Review, 23(4), 660-679.

Eisenhardt, K.M., \& Graebner, M.E. (2007). Theory building from cases: Opportunities and challenges. Academy of Management Journal, 50(1), 25-32.

Eisenhardt, K.M., \& Martin, J.A. (2000). Dynamic capabilities: what are they? Strategic Management Journal, 21(10-11), 1105-1121.

Ethiraj, S.K., Kale, P., Krishnan, M.S., \& Singh, J.V. (2005). Where do capabilities come from and how do they matter? A study in the software services industry. Strategic Management Journal, 26(1), 25-45.

Felin, T., Foss, N.J., Heimeriks, K.H., \& Madsen, T.L. (2012). Microfoundations of routines and capabilities: Individuals, processes, and structure. Journal of Management Studies, 49(8), 1351-1374

Ford, D. (2011). IMP and service-dominant logic: Divergence, convergence and development. Industrial Marketing Management, 40(2), 231-239.

Foss, N.J., Laursen, K., \& Pedersen, T. (2011). Linking customer interaction and innovation: The mediating role of new organizational practices. Organization Science, 22(4), 980-999.

Freeman, E.R. (1994). The politics of stakeholder theory: Some future directions. Business Ethics Quarterly, 4(4), 409-421.

Fuchs, C., Prandelli, E., Schreier, M., \& Dahl, D.W. (2013). All that is users might not be gold: How labeling products as user designed backfires in the context of luxury fashion brands. Journal of Marketing, 77(5), 75-91.

Garcia-Castro, R., \& Aguilera, R. V. (2015). Incremental value creation and appropriation in world with multiple stakeholders. Strategic Management Journal, 36(1), 137-147.

Garnier, J. -P. (2008). Rebuilding the R\&D engine in big pharma. Harvard Business Review, $86(5), 68-77$

Gebauer, J., Füller, J., \& Pezzei, R. (2013). The dark and the bright side of co-creation: Triggers of member behavior in online innovation communities. Journal of Busines Research, 66(9), 1516-1527.

Gebhardt, G.F., Carpenter, G.S., \& Sherry, J.F. (2006). Creating a market orientation: A longitudinal, multifirm, grounded analysis of cultural transformation. Journal of Marketing, 70(4), 37-55.

Gioia, D.A., Corley, K.G., \& Hamilton, A.L. (2013). Seeking qualitative rigor in inductive research notes on the gioia methodology. Organizational Research Methods, 16(1), 15-31.

Gnyawali, D.R., \& Park, B. -J. (2011). Co-opetition between giants: Collaboration with competitors for technological innovation. Research Policy, 40(5), 650-663.

Grant, R.M. (1996). Prospering in dynamically-competitive environments: Organizational capability as knowledge integration. Organization Science, 7(4), 375-387.

Grant, R.M., \& Baden-Fuller, C. (2004). A knowledge accessing theory of strategic alliances. Journal of Management Studies, 41(1), 61-84.

Gulati, R. (1999). Network location and learning: The influence of network resources and firm capabilities on alliance formation. Strategic Management Journal, 20(5), 397-420.

Harrison, J.S., Bosse, D.A., \& Phillips, R.A. (2010). Managing for stakeholders, stakeholder utility functions, and competitive advantage. Strategic Management Journal, 31(1), 58-74.

Hart, S.L., \& Sharma, S. (2004). Engaging fringe stakeholders for competitive imagination. The Academy of Management Executive, 18(1), 7-18 (1993-2005).

Hoopes, D.G., \& Madsen, T.L. (2008). A capability-based view of competitive heterogeneity. Industrial and Corporate Change, 17(3), 393-426.

Horn, C., \& Brem, A. (2013). Strategic directions on innovation management - A conceptual framework. Management Research Review, 36(10), 939-954.

Hoyer, W.D., Chandy, R., Dorotic, M., Krafft, M., \& Singh, S.S. (2010). Consumer cocreation in new product development. Journal of Service Research, 13(3), 283-296.

Hsiao, R.L., Tsai, D.H., \& Lee, C.F. (2012). Collaborative knowing: The adaptive nature of cross-boundary spanning. Journal of Management Studies, 49(3), 463-491.

Huang, K. -F., Lin, K. -H., Wu, L. -Y., \& Yu, P. -H. (2015). Absorptive capacity and autonomous R\&D climate roles in firm innovation. Journal of Business Research, 68(1), 87-94.

Hughes, B., \& Wareham, J. (2010). Knowledge arbitrage in global pharma: A synthetic view of absorptive capacity and open innovation. RED Management, 40(3), 324-343.

Huikkola, T., Ylimäki, J., \& Kohtamäki, M. (2013). Joint learning in R\&D collaborations and the facilitating relational practices. Industrial Marketing Management, 42(7), 1167-1180.

Hult, T.M., Mena, J.A., Ferrell, O.C., \& Ferrell, L. (2011). Stakeholder marketing: A definition and conceptual framework. AMS Review, 1(1), 44-65.

Jaworski, B.J., \& Kohli, A.K. (1993). Market orientation: Antecedents and consequences. Journal of Marketing, 57(3), 53-70.

Jick, T.D. (1979). Mixing qualitative and quantitative methods: Triangulation in action. Administrative Science Quarterly, 24(4), 602-611.

Kraaijenbrink, J., Spender, J. -C., \& Groen, A.J. (2010). The resource-based view: A review and assessment of its critiques. Journal of Management, 36(1), 349-372.

Krasnikov, A., \& Jayachandran, S. (2008). The relative impact of marketing, research-anddevelopment, and operations capabilities on firm performance. Journal of Marketing, $72(4), 1-11$

Lane, P.J., Koka, B.R., \& Pathak, S. (2006). The reification of absorptive capacity: A critica review and rejuvenation of the construct. Academy of Management Review, 31(4), 833-863.

Laursen, K., \& Salter, A. (2006). Open for innovation: The role of openness in explaining nnovation performance among U.K. manufacturing firms. Strategic Management Journal, 27(2), 131-150.
Leischnig, A., Geigenmueller, A., \& Lohmann, S. (2014). On the role of alliance management capability, organizational compatibility, and interaction quality in interorganizational technology transfer. Journal of Business Research, 67(6), 1049-1057.

Lewin, A.Y., Massini, S., \& Peeters, C. (2011). Microfoundations of internal and external absorptive capacity routines. Organization Science, 22(1), 81-98.

Lin, H. -E., McDonough, E.F., Lin, S. -J., \& Lin, C.Y. -Y. (2012). Managing the exploitation/exploration paradox: The role of a learning capability and innovation ambidexterity. Journal of Product Innovation Management, 30(2), 262-278.

Lindgreen, A., Hingley, M.K., Grant, D.B., \& Morgan, R.E. (2012). Value in business and industrial marketing: Past, present, and future. Industrial Marketing Management, 41(1), 207-214

Lorenzoni, G., \& Lipparini, A. (1999). The leveraging of interfirm relationships as a distinctive organizational capability: A longitudinal study. Strategic Management Journal, 20(4), 317-338

MacInnis, D.J. (2011). A framework for conceptual contributions in marketing. Journal of Marketing, 75(4), 136-154

Mahr, D., Lievens, A., \& Blazevic, V. (2014). The value of customer cocreated knowledge during the innovation process. Journal of Product Innovation Management, 31(3), 599-615.

Malhotra, A., Gosain, S., \& El Sawy, O.A. (2005). Absorptive capacity configurations in supply chains: Gearing for partner-enabled market knowledge creation. MIS Quarterly, 29(1), 145-187.

March, J.G. (1991). Exploration and exploitation in organizational learning. Organization Science, 2(1), 71-87.

Menguc, B., Auh, S., \& Yannopoulos, P. (2014). Customer and supplier involvement in design: The moderating role of incremental and radical innovation capability. Journal of Product Innovation Management, 31(2), 313-328.

Mishra, A.A., \& Shah, R. (2009). In union lies strength: Collaborative competence in new product development and its performance effects. Journal of Operations Management, 27(4), 324-338.

Mitrega, M., Forkmann, S., Ramos, C., \& Henneberg, S.C. (2012). Networking capability in business relationships - Concept and scale development. Industrial Marketing Management, 41(5), 739-751.

Molina-Morales, X.F., Martínez-Fernández, T.M., \& Torlò, V.J. (2011). The dark side of trust: The benefits, costs and optimal levels of trust for innovation performance. Long Range Planning, 44(2), 118-133.

Möller, K., Rajala, A., \& Svahn, S. (2005). Strategic business nets-Their type and management. Journal of Business Research, 58(9), 1274-1284.

Möller, K., \& Törrönen, P. (2003). Business suppliers' value creation potential: A capability-based analysis. Industrial Marketing Management, 32(2), 109-118.

MSI (2014). 2014-2016 Research priorities. Cambridge, MA: Marketing Science Institute.

Nonaka, I., \& Takeuchi, H. (1995). The knowledge-creating company: How Japanese companies create the dynamics of innovation. New York: Oxford university press.

O'Mahony, S., \& Bechky, B.A. (2008). Boundary organizations: Enabling collaboration among unexpected allies. Administrative Science Quarterly, 53(3), 422-459.

Pablo, A.L., Reay, T., Dewald, J.R., \& Casebeer, A.L. (2007). Identifying, enabling and managing dynamic capabilities in the public sector. Journal of Management Studies, 44(5), 687-708.

Perks, H., Gruber, T., \& Edvardsson, B. (2012). Co-creation in radical service innovation: A systematic analysis of microlevel processes. Journal of Product Innovation Management, 29(6), 935-951.

Perks, H., \& Jeffery, R. (2006). Global network configuration for innovation: A study of international fibre innovation. RED Management, 36(1), 67-83.

Perks, H., \& Moxey, S. (2011). Market-facing innovation networks: How lead firms partition tasks, share resources and develop capabilities. Industrial Marketing Management, 40(8), 1224-1237.

Poetz, M.K., \& Schreier, M. (2012). The value of crowdsourcing: Can users really compete with professionals in generating new product ideas? Journal of Product Innovation Management, 29(2), 245-256.

Powell, W.W., Koput, K.W., \& Smith-Doerr, L. (1996). Interorganizational collaboration and the locus of innovation: Networks of learning in biotechnology. Administrative Science Quarterly, 41(1), 116-145.

Pretty, J.N. (1995). Participatory learning for sustainable agriculture. World Development, 23(8), 1247-1263.

Pullen, A.J.J., de Weerd-Nederhof, P.C., Groen, A.J., \& Fisscher, O.A.M. (2012). Open innovation in practice: Goal complementarity and closed NPD networks to explain differences in innovation performance for SMEs in the medical devices sector. Journal of Product Innovation Management, 29(6), 917-934.

Ramaswamy, V., \& Gouillart, F. (2010). Building the co-creative enterprise. Harvard Business Review, 88(10), 100-109.

Ritter, T., \& Gemünden, H.G. (2003). Network competence: Its impact on innovation success and its antecedents. Journal of Business Research, 56(9), 745-755.

Salvato, C., \& Rerup, C. (2011). Beyond collective entities: Multilevel research on organizational routines and capabilities. Journal of Management, 37(2), 468-490.

Schreiner, M., Kale, P., \& Corsten, D. (2009). What really is alliance management capability and how does it impact alliance outcomes and success? Strategic Management Journal, 30(13), 1395-1419.

Shah, S.K., \& Corley, K.G. (2006). Building better theory by bridging the quantitative-qualitative divide. Journal of Management Studies, 43(8), 1821-1835.

Singh, J., \& Sirdeshmukh, D. (2000). Agency and trust mechanisms in consumer satisfaction and loyalty judgments. Journal of the Academy of Marketing Science, 28(1), 150-167.

Sluyts, K., Matthyssens, P., Martens, R., \& Streukens, S. (2011). Building capabilities to manage strategic alliances. Industrial Marketing Management, 40(6), 875-886. 
Song, M., \& Thieme, J. (2009). The role of suppliers in market intelligence gathering for radical and incremental innovation. Journal of Product Innovation Management, 26(1), 43-57.

Spithoven, A., Clarysse, B., \& Knockaert, M. (2011). Building absorptive capacity to organise inbound open innovation in traditional industries. Technovation, 31(1), 10-21.

Storbacka, K. (2011). A solution business model: Capabilities and management practices for integrated solutions. Industrial Marketing Management, 40(5), 699-711.

Suddaby, R. (2006). From the editors: What grounded theory is not. Academy of Management Journal, 49(4), 633-642.

Teece, D.J. (2007). Explicating dynamic capabilities: The nature and microfoundations of (sustainable) enterprise performance. Strategic Management Journal, 28(13), 1319-1350.

Teece, D. J., Pisano, G., \& Shuen, A. (1997). Dynamic capabilities and strategic management. Strategic Management Journal, 18(7), 509-533.

Van Bockhaven, W., Matthyssens, P., \& Vandenbempt, K. (2013). Structural antecedents of institutional entrepreneurship in industrial networks: A critical realist explanation. Industrial Marketing Management, 42(3), 405-420.
Van Den Bosch, F.A.J., Volberda, H.W., \& De Boer, M. (1999). Coevolution of firm absorptive capacity and knowledge environment: Organizational forms and combinative capabilities. Organization Science, 10(5), 551-568.

Vargo, S.L., \& Lusch, R.F. (2008). Service-dominant logic: Continuing the evolution. Journal of the Academy of Marketing Science, 36(1), 1-10.

Volberda, H.W., Foss, N.J., \& Lyles, M.A. (2010). Absorbing the concept of absorptive capacity: How to realize its potential in the organization field. Organization Science, 21(4), 931-951.

Vorhies, D.W., \& Morgan, N.A. (2005). Benchmarking marketing capabilities for sustainable competitive advantage. Journal of Marketing, 69(1), 80-94.

Waligo, V.M., Clarke, J., \& Hawkins, R. (2014). The 'leadership-stakeholder involvement capacity' nexus in stakeholder management. Journal of Business Research, 67(7), 1342-1352.

Yin, R.K. (2009). Case study research: Design and methods, vol. 5, Newbury Park, CA: Sage Publications.

Zahra, S.A., \& George, G. (2002). Absorptive capacity: A review, reconceptualization, and extension. Academy of Management Review, 27, 185-203. 